\title{
NUTRIENTS IN THE CASSAVA (Manihot esculenta Crantz) LEAF MEAL AT THREE AGES OF THE PLANT ${ }^{1}$
}

\author{
Carmen WOBETO ${ }^{2, *}$, Angelita Duarte CORRÊA ${ }^{3}$, Celeste Maria Pato de ABREU ${ }^{3}$, \\ Custódio Donizete dos SANTOS ${ }^{3}$, José Renato de ABREU ${ }^{4}$
}

\section{SUMMARY}

The high number of cassava cultivars adapted to many different regions provides a wide variation in the chemical composition of cassava leaves meal (CLM). Therefore, the contents of some nutrients in CLM from five cultivars at three ages of the plant were investigated in order to select the cultivars and ages with superior levels of these nutrients. When the plants were 12 months old, the highest levels of crude protein (CP), $\beta$-carotene, iron, magnesium, phosphorus and sulfur were observed. The IAC 289-70 cv. showed the highest levels of magnesium, as well as considerable contents of $\mathrm{CP}, \beta$-carotene, iron, zinc and sulfur, which did not differ statistically from the cultivars showing the highest levels of these nutrients.

Keywords: cassava leaves, cultivar, minerals, vitamin, crude protein.

\section{RESUMO}

NUTRIENTES NA FARINHA DE FOLHAS DE MANDIOCA (Manihot esculenta Crantz) EM TRÊS IDADES DA PLANTA. O número elevado de cultivares de mandioca adaptados às mais diversas regiões confere ampla variação na composição química da farinha de folhas de mandioca (FFM). Portanto, foram investigados os teores de alguns nutrientes nas FFM de cinco cultivares em três idades da planta, a fim de selecionar cultivares e idades com níveis superiores destes nutrientes. Aos 12 meses de idade da planta, observaram-se os maiores níveis de proteína bruta (PB), $\beta$-caroteno, ferro, magnésio, fósforo e enxofre. O cultivar IAC 289-70 apresentou os maiores níveis de magnésio, assim como teores apreciáveis de $\mathrm{PB}, \beta$-caroteno, ferro, zinco e enxofre, pois não diferiu estatisticamente dos cultivares com os níveis mais elevados destes nutrientes.

Palavras-chave: folhas de mandioca, cultivar, minerais, vitamina, proteína bruta.

\section{1 - INTRODUCTION}

According to FAO's estimates, in 1998-2000 some 16.7 million Brazilians (approximately $10 \%$ of the population) were chronically undernourished [13]. Several alternatives have been proposed to ease this problem. The cassava leaf meal (CLM) has been used in the combat of malnutrition and has been included in school meals or given away as packages in basic food packs distributed to families among low income populations [18, 31].

Although the roots are conventionally used, the use of the leaves is favourable as they provide a positive balance in the nutritional quality, since they are a source of fiber, minerals and vitamins. It is also worth mentioning their low production costs, because the leaves are considered residues and they do not compete with the main commercial product, the roots [24].

However, the high number of cultivars adapted to various regions is a decisive factor for the wide variation in the

\footnotetext{
${ }^{1}$ Recebido para publicação em 20/3/2006. Aceito para publicação em 20/10/2006 (001695)

${ }^{2}$ Departamento de Agronomia

Universidade do Estado de Mato Grosso (UNEMAT)

Av. São João, s/no Bairro Cavalhada I, CEP 78200-000, Cáceres (MT),

E-mail:wobeto2003@yahoo.com.br

${ }^{3}$ Departamento de Química,

Universidade Federal de Lavras (UFLA)

${ }^{4}$ Departamento de Agroquímica e Agrobioquímica,

Universidade Federal de Lavras (UFLA)

* A quem a correspondência deve ser enviada
}

chemical composition of CLM. In addition, there are no data concerning the influence of the plant age on the levels of minerals. Therefore, the contents of some CLM nutrients in five cultivars at three ages of the plant (TAP) were investigated in order to select the cultivar and age with higher levels of these nutrients.

\section{2 - MATERIAL AND METHODS}

\section{1 - Collection and preparation of the samples}

The ripe cassava leaves of five cultivars, Ouro do Vale, Mantiqueira IAC 24-2 (MANT.IAC), IAC 289-70, Maracanã and Mocotó, from the experimental area pertaining to the Agricultural Department of the Universidade Federal de Lavras (UFLA) were collected at TAP in the morning in October, 2001 (12 months), January, 2002 (15 months) and March, 2002 (17 months). They were transported in plastic bags to the drying place and were dried in the shade at room temperature in a closed and airy room. On the $10^{\text {th }}$ day under drying, as the leaves from the first collection were still moist for grinding, they were taken to a ventilated oven at $30{ }^{\circ} \mathrm{C}$ for $90 \mathrm{~min}$, after removing their petioles, and this same procedure was adopted for all other collections. Afterwards, the leaves were triturated in a 40-mesh mill. The CLM were stored in glass recipients and protected from the light until the beginning of the analyses at the Biochemistry Laboratory belonging to the Chemical Department/UFLA. 


\section{2 - Physical and chemical analyses}

The physical and chemical analyses were carried out by determining moisture and crude protein (CP) [4]; $\beta$-carotene [19]; total vitamin C by Roe and Kuether's colorimeter method [32]; neutral detergent fiber (NDF) by Van Soest and Wine's method [30]; and some minerals - iron, zinc, manganese, copper, magnesium, calcium, phosphorus, potassium and sulfur [17].

The entirely randomized statistical design was used with a factorial scheme $5 \times 3 \times 3$, that is, five cultivars, three plant ages with three replicates. The Tuckey test at $5 \%$ probability was used to compare the averages [22].

\section{3 - RESULTS AND DISCUSSION}

The average moisture contents of both the leaves and CLM (g/100 g) were $70.46 \pm 1.15$ and $9.16 \pm 0.81$, respectively.

In variance analysis, significant differences were observed at $1 \%$ or $5 \%$ probability by the $\mathrm{F}$ test in all other parameters studied (Tables 1 and 2). It was found that neither the cultivar and plant age affected the results, since the interaction between both parameters showed significant differences at 1 or $5 \%$ probability by the $\mathrm{F}$ test; for this reason, the average test Tukey was used in order to verify the differences among treatments.

Table 3 shows the average contents in dry matter (DM) of $\mathrm{CP}, \beta$-carotene, vitamin $\mathrm{C}$ and $\mathrm{NDF}$ in CLM of the five cultivars at TAP. The highest contents of $\mathrm{CP}$ and $\beta$-carotene were observed when the plant was 12 months old. The cultivars, Mocotó and Maracanã had highest levels of $\mathrm{CP}$ and $\beta$-carotene, respectively. However, the IAC 289-70 cv. at 12-months, also showed no significant differences with them in both parameters.

TABLE 1 - Summary of the results from the variance analysis of some nutrients in cassava leaf meal at three ages of the plant.

\begin{tabular}{llcccc}
\hline \multirow{2}{*}{ Source } & \multicolumn{5}{c}{ Mean square $^{1}$} \\
\cline { 2 - 6 } & DF $^{2}$ & $\begin{array}{c}\text { Crude } \\
\text { protein }\end{array}$ & $\beta$ - carotene & Vitamin C & NDF $^{3}$ \\
\hline Cultivar (C) & 4 & $3.911^{* *}$ & $837.187^{* *}$ & $3222.881^{* *}$ & $52.563^{* *}$ \\
Age (A) & 2 & $305.600^{* *}$ & $18176.966^{* *}$ & $36265.336^{* *}$ & $9.982^{* *}$ \\
$\mathrm{C} \times \mathrm{A}$ & 8 & $15.474^{* *}$ & $133.557^{* *}$ & $1094.580^{* *}$ & $4.978^{*}$ \\
Residual & 30 & 1.049 & 14.304 & 6.384 & 1.788 \\
VC ${ }^{4}(\%)$ & \multicolumn{7}{c}{3.64} & 4.30 & 2.80 & 5.33 \\
\hline${ }^{1 * * * *}$ Significance of $\mathrm{F}$ test at $\mathrm{p}=0.05$ or 0.01, respectively; ${ }^{2} \mathrm{DF}=$ Degrees of freedom; \\
${ }^{3} \mathrm{NDF}=$ Neutral detergent fiber; and ${ }^{4} \mathrm{VC}=$ Variation coefficient.
\end{tabular}

In other studies, higher contents for $\mathrm{CP}$ were also reported at the $12^{\text {th }}$ month after planting [8] in the aerial part of the upper third part in 10 cassava cultivars, as well as for $\beta$-carotene [7] in CLM of three cultivars. Regardless of the cultivars and plant age, the variation in CP levels in CLM is within the range from 17.8 to $37.40 \mathrm{~g} / 100 \mathrm{~g} \mathrm{DM}$, according to the available literature $[1,12,16,21,25,26]$.

In relation to $\beta$-carotene, the levels found in CLM, at all TAP are above those described by CORREA [10], who evaluated different drying temperatures of the leaves from the Baiana cv. and found significant differences, since the lowest levels of $\beta$-carotene were observed when the leaves

TABLE 2 - Summary of the results from variance analysis of the minerals in cassava leaf meal at three ages of the plant.

\begin{tabular}{|c|c|c|c|c|c|c|c|c|c|c|}
\hline \multirow[t]{2}{*}{ Source } & \multicolumn{10}{|c|}{ Mean square $^{1}$} \\
\hline & $\mathrm{DF}^{2}$ & $\mathrm{Fe}$ & $\mathrm{Zn}$ & Mn & $\mathrm{Cu}$ & $\mathrm{Mg}$ & $\mathrm{Ca}$ & $\mathbf{P}$ & $\mathrm{K}$ & $\mathrm{s}$ \\
\hline Cultivar (C) & 4 & $2317.43^{* *}$ & $882.04^{* *}$ & $3636.037^{* \star}$ & $152.64^{* *}$ & $0.037^{* *}$ & $1.272^{\star \star}$ & $0.001^{* *}$ & $0.04^{* *}$ & $0.01^{* *}$ \\
\hline Age $(A)$ & 2 & $27959.44^{* *}$ & $86.44^{* *}$ & $8408.407^{* *}$ & $53.250^{* *}$ & $0.0005^{*}$ & $0.054^{* *}$ & $0.006^{* *}$ & $0.26^{* *}$ & $0.01^{* *}$ \\
\hline$C \times A$ & 8 & $770.55^{\star *}$ & $81.07^{* *}$ & $1967.374^{* *}$ & $83.675^{* *}$ & $0.001^{* *}$ & $0.032^{* *}$ & $0.002^{* *}$ & $0.07^{* *}$ & $0.01^{* *}$ \\
\hline Residual & 30 & 36.68 & 3.29 & 16.081 & 0.120 & 0.0001 & 0.003 & 0.000 & 0.002 & 0.0002 \\
\hline$V^{3}(\%)$ & & 3.62 & 3.56 & 2.83 & 3.63 & 4.75 & 3.58 & 3.12 & 3.26 & 3.82 \\
\hline
\end{tabular}

$1 * / *$ Significance of $\mathrm{F}$ test at $\mathrm{P}=0.05$ or 0.01 , respectively; ${ }^{2} \mathrm{DF}=$ Degrees of freedom; and ${ }^{3} \mathrm{VC}=$ Variation coefficient.

TABLE 3 - Average contents, in $100 \mathrm{~g}$ dry matter, of crude protein, $\beta$-carotene, vitamin $\mathrm{C}$ and neutral detergent fiber (NDF) in cassava leaf meal at three ages of the plant.

\begin{tabular}{|c|c|c|c|c|c|c|}
\hline \multirow[t]{2}{*}{ Cultivars } & \multicolumn{3}{|c|}{ Crude protein (g) } & \multicolumn{3}{|c|}{$\beta$-carotene (mg) } \\
\hline & $12 \mathrm{mo}$ & $15 \mathrm{mo}$ & $17 \mathrm{mo}$ & $12 \mathrm{mo}$ & $15 \mathrm{mo}$ & $17 \mathrm{mo}$ \\
\hline Ouro do Vale & $29.17 \mathrm{aD}$ & $28.65 \mathrm{aA}$ & $25.08 \mathrm{bAB}$ & $124.24 \mathrm{aB}$ & $54.85 \mathrm{cBC}$ & $91.80 \mathrm{bA}$ \\
\hline Maracanã & $33.28 \mathrm{aBC}$ & $26.21 \mathrm{bB}$ & $24.71 \mathrm{bB}$ & $137.38 \mathrm{aA}$ & $70.85 \mathrm{cA}$ & $92.50 \mathrm{bA}$ \\
\hline MANT.IAC & $32.74 \mathrm{aC}$ & $26.48 \mathrm{bAB}$ & $24.12 \mathrm{cB}$ & $113.83 \mathrm{aC}$ & $50.36 \mathrm{cC}$ & $58.49 \mathrm{bC}$ \\
\hline IAC 289-70 & $35.23 \mathrm{aAB}$ & $24.92 \mathrm{bB}$ & $23.25 \mathrm{bB}$ & 131.14 aAB & $60.21 \mathrm{cB}$ & 82.77 bB \\
\hline Mocotó & $35.90 \mathrm{aA}$ & $24.67 \mathrm{cB}$ & $27.18 \mathrm{bA}$ & $126.57 \mathrm{aB}$ & $58.88 \mathrm{cBC}$ & $66.58 \mathrm{bC}$ \\
\hline Cultivars & \multicolumn{3}{|c|}{ Vitamin C (mg) } & \multicolumn{3}{|c|}{ NDF (g) } \\
\hline Ouro do Vale & $64.12 \mathrm{bA}$ & $50.28 \mathrm{cC}$ & $175.42 \mathrm{aB}$ & $24.07 \mathrm{~B}$ & $22.45 B$ & $21.60 \mathrm{C}$ \\
\hline Maracanã & $61.31 \mathrm{cAB}$ & $100.93 \mathrm{bA}$ & $181.90 \mathrm{aA}$ & $23.96 \mathrm{~B}$ & $22.96 \mathrm{~B}$ & $22.01 \mathrm{C}$ \\
\hline MANT.IAC & $67.28 \mathrm{bA}$ & $51.61 \mathrm{cC}$ & $140.04 \mathrm{aC}$ & $24.78 \mathrm{~B}$ & $26.89 \mathrm{~A}$ & $25.65 A B$ \\
\hline IAC 289-70 & $43.64 \mathrm{bC}$ & $48.47 \mathrm{bC}$ & $94.98 \mathrm{aD}$ & $28.02 \mathrm{~A}$ & $29.62 A$ & $28.31 \mathrm{~A}$ \\
\hline Mocotó & $55.72 \mathrm{cB}$ & $75.14 \mathrm{bB}$ & $141.70 \mathrm{aC}$ & $23.63 \mathrm{bB}$ & $28.08 a A$ & $24.47 \mathrm{bBC}$ \\
\hline
\end{tabular}

Averages followed by the same small letter in the lines and capital letters in the columns do not differ with each other (Tukey test $\mathrm{p} \leq 0.05$ ). 
were dried in the shade (64.88 $\mathrm{mg} / 100 \mathrm{~g} \mathrm{DM})$, and the highest ones when the leaves were dried in an oven at $30^{\circ} \mathrm{C}$ (84.83 mg/100 g DM). Therefore, the differences in the levels of this nutrient are probably due to the cultivars, plant ages and also to the temperatures used in drying the leaves.

When the plants were 17-months old, higher levels of vitamin $\mathrm{C}$ were observed for all cultivars, with prominence for Maracanã cv. Though, the age had no influence on NDF levels, except for Mocotó cv., but the IAC 289-70 cv. had the highest levels of NDF.

When plants were 17-months old, which is a phase characterized by starch accumulation, the highest vitamin C levels are according to CORRÊA et al. [11] who also obtained higher contents of this vitamin in the ripe shadowdried plants at the starch accumulation phase (108.62 mg/ $100 \mathrm{~g} \mathrm{DM})$, in comparison with the leaf development phase (72.91 mg/100 g DM).

The NDF range of contents (21.60 to $29.62 \mathrm{~g} / 100 \mathrm{~g} \mathrm{DM}$ ) found in the present study is similar to those obtained by CORREA et al. [11]. Furthermore RAVINDRAN \& RAVINDRAN [25], when evaluating the nutrient contents in CLM from leaves at different maturity stages, found that the contents of crude fibers were higher in the ripe leaves (27.4 g/100 g DM). Thus, the CLM is a source of fiber, because the levels it presents are comparable with those in other leaves, such as total dietary fiber in the sweet potato leaves -22.6 to $37.6 \mathrm{~g} / 100 \mathrm{~g}$ DM [3] and in peanut leaves - 30.9 to $41.7 \mathrm{~g} / 100 \mathrm{~g}$ DM [2].

Table 4 presents the contents of iron and zinc in CLM of the five cultivars at TAP. In general, the iron levels decreased with the maturity of the vegetal, with prominence for the Mocotó cv. (12 mo). However, IAC 289-70 did not differ significantly and at 15 and 17-months old, it presented the highest levels of this mineral. The cultivars Ouro do Vale and Mocotó showed higher contents of zinc at TAP, whereas the IAC 289-70 cv. (12 months) did not differ significantly.
In the scientific literature, the following variations are described (mg/kg DM) for iron - 61.5 to 270.0 [5, 9, 16, 23] and for the zinc - 30.0 to 63.7 [9,16, 23,]. It was observed that the iron levels in CLM under study are included into this range, as well as those of zinc, except for Ouro do Vale cv. (15 mo) which were superior. Probably, the cultivars, the plant ages, and the chemical composition of the soil influenced the observed differences.

By comparing the contents of iron in the analyzed CLM, in $\mathrm{mg} / \mathrm{kg}$ fresh matter (107.99 to 205.93) with the conventional sources of this mineral [14], such as liver (121.0) and egg yolk (58.7), it was observed that CLM are rich in iron. However, it should also be taken into account that the iron of plant origin is less absorbed than the one from animal origin [29].

Table 5 shows the average contents of manganese, copper and sulfur in CLM of the five cultivars at TAP. The highest levels of manganese were observed at 15 months, except for the Maracanã cv. that presented the highest ones at 17 months. In the other ages, however, the Mocotó cv. showed prominence. The Maracanã $\mathrm{cv}$. at TAP contained the highest copper levels, mainly at 17 months. The sulfur levels were observed to be higher at 12 months, except for the Ouro do Vale cv. Both cultivars Mocotó and IAC 289-70 were prominent, since they showed the highest sulfur levels.

The following variations in $\mathrm{mg} / \mathrm{kg}$ DM in CLM were observed in the literature: from 50.3 to 263.0 for manganese and from 6.2 to 50.0 for copper [ $1,9,23]$. Thus, in the present study, the contents of manganese and copper observed are included in these variation ranges. CHAVEZ et al. [9] found sulfur contents from 0.23 to $0.30 \mathrm{~g} / 100 \mathrm{~g}$ DM in the leaves of 20 cassava clones, which were slightly less than the ones observed in the present research (0.28 to $0.41 \mathrm{~g} / 100 \mathrm{~g} \mathrm{DM})$. Probably, the factors influencing these differences are the genetic characteristics of the cultivars, the vegetal maturity, and the sulfur levels in the soil.

TABLE 4 - Average contents, in $\mathrm{mg} / \mathrm{kg}$ dry matter, of iron and zinc in cassava leaf meal at three ages of the plant.

\begin{tabular}{|c|c|c|c|c|c|c|}
\hline \multirow[t]{2}{*}{ Cultivars } & \multicolumn{3}{|c|}{ Iron } & \multicolumn{3}{|c|}{ Zinc } \\
\hline & $12 \mathrm{mo}$ & $15 \mathrm{mo}$ & $17 \mathrm{mo}$ & $12 \mathrm{mo}$ & $15 \mathrm{mo}$ & $17 \mathrm{mo}$ \\
\hline Ouro do Vale & $212.10 \mathrm{aAB}$ & $141.80 \mathrm{bB}$ & $120.07 \mathrm{cC}$ & $51.67 \mathrm{bA}$ & $67.10 \mathrm{aA}$ & $64.10 \mathrm{aA}$ \\
\hline Maracanã & $202.90 \mathrm{aB}$ & $125.40 \mathrm{bC}$ & $126.00 \mathrm{bBC}$ & 42.77abB & $39.97 \mathrm{bC}$ & $45.53 \mathrm{aC}$ \\
\hline IAC 289-70 & $224.47 \mathrm{aA}$ & 203.47 bA & $152.17 \mathrm{cA}$ & $50.63 \mathrm{~A}$ & $54.23 \mathrm{~B}$ & $51.60 \mathrm{~B}$ \\
\hline Mocotó & $225.60 \mathrm{aA}$ & $132.83 \mathrm{cBC}$ & $148.57 \mathrm{bA}$ & $52.37 \mathrm{bA}$ & $63.20 \mathrm{aA}$ & $64.07 \mathrm{aA}$ \\
\hline
\end{tabular}

Averages followed by the same small letter in the lines and capital letters in the columns do not differ with each other (Tukey test $\mathrm{p} \leq 0.05$ ).

TABLE 5 - Average contents of manganese, copper and sulfur in cassava leaf meal at three ages of the plant.

\begin{tabular}{|c|c|c|c|c|c|c|c|c|c|}
\hline \multirow[t]{2}{*}{ Cultivars } & \multicolumn{3}{|c|}{ Manganese (mg/kg in DM) } & \multicolumn{3}{|c|}{ Copper (mg/kg in DM) } & \multicolumn{3}{|c|}{ Sulfur (g/100 g in DM) } \\
\hline & $12 \mathrm{mo}$ & $15 \mathrm{mo}$ & $17 \mathrm{mo}$ & $12 \mathrm{mo}$ & $15 \mathrm{mo}$ & $17 \mathrm{mo}$ & $12 \mathrm{mo}$ & $15 \mathrm{mo}$ & $17 \mathrm{mo}$ \\
\hline Ouro do Vale & $66.50 \mathrm{cD}$ & $165.23 \mathrm{aB}$ & $145.70 \mathrm{bC}$ & $8.60 \mathrm{aC}$ & $8.07 \mathrm{aB}$ & $6.07 \mathrm{bC}$ & 0.33 bD & $0.36 \mathrm{aA}$ & $0.32 \mathrm{bC}$ \\
\hline Maracanã & $102.33 \mathrm{cC}$ & $168.20 \mathrm{bB}$ & 192.87 aA & $12.00 \mathrm{bA}$ & $9.43 \mathrm{cA}$ & $29.10 \mathrm{aA}$ & $0.38 \mathrm{aC}$ & $0.31 \mathrm{bB}$ & $0.35 \mathrm{aB}$ \\
\hline MANT.IAC & $122.20 \mathrm{bB}$ & $138.10 \mathrm{aC}$ & $115.03 \mathrm{bE}$ & $8.50 \mathrm{aC}$ & $7.83 \mathrm{aB}$ & $6.00 \mathrm{bC}$ & $0.38 \mathrm{aBC}$ & $0.31 \mathrm{bB}$ & $0.32 \mathrm{bC}$ \\
\hline IAC 289-70 & $126.30 \mathrm{bB}$ & $141.37 \mathrm{aC}$ & 128.23 bD & $10.07 \mathrm{aB}$ & $4.05 \mathrm{cC}$ & $7.60 \mathrm{bB}$ & $0.41 \mathrm{aAB}$ & $0.32 \mathrm{bB}$ & $0.28 \mathrm{cD}$ \\
\hline Mocotó & $157.97 \mathrm{bA}$ & $190.10 \mathrm{aA}$ & 163.50 bB & $10.30 \mathrm{aB}$ & $8.10 \mathrm{bB}$ & $7.30 \mathrm{cB}$ & $0.41 \mathrm{aA}$ & $0.34 \mathrm{bAB}$ & $0.41 \mathrm{aA}$ \\
\hline
\end{tabular}

Averages followed by the same small letter in the lines and capital letters in the columns do not differ with each other (Tukey test $\mathrm{p} \leq 0.05)$. DM $=$ dry matter. 
Table 6 shows the average contents of magnesium, calcium, phosphorus and potassium in CLM from the five cultivars at TAP. The IAC 289-70 cv. showed the highest contents of magnesium at all ages, whereas the Ouro do Vale cv. had the highest contents of calcium, but predominating of 17 months of age. The highest levels of phosphorus and potassium were observed at 12 months, except for the Ouro do Vale cv. The Mocotó cv. (12 months) presented the highest levels of both minerals.

When comparing the contents of magnesium and calcium in CLM ( $\mathrm{g} / 100 \mathrm{~g} \mathrm{DM})$ with data reported in the available literature, that is, 0.26 to 0.97 for magnesium [9, 16, 20, 23 ] and 0.04 to 1.63 for calcium [ $1,6,15,16,23,9]$, lower magnesium and similar calcium contents were observed, except for the Ouro do Vale cv. ones with higher levels for calcium at all TAP. Probably, the observed differences are due to the cultivars, the plant ages, and the levels of these nutrients in the soil.

The levels of phosphorus and potassium observed in these five cassava cultivars at TAP coincide with those for CLM reported in the literature, as including a variation (g/100 g DM), from 0.07 to 0.35 of phosphorus [5, 6, 9, 15, $16,23$,$] and 0.8$ to 1.69 of potassium $[9,16,23]$.

The CLM analyzed in the present study are particularly rich in proteins, $\beta$ - carotene, vitamin $\mathrm{C}$, iron, zinc, manganese, magnesium and calcium. In Table 7 the levels of these nutrients in CLM are compared with other leaves.

\section{4 - CONCLUSIONS}

Considering the age of the plants under study, at 12 months highest levels of CP, $\beta$-carotene, iron, phosphorus, and sulfur were shown. However, the cassava leaf meal (CLM) from the 17-month old plants contained the highest vitamin $\mathrm{C}$, zinc, and calcium levels.

The Maracanã cv. presented the highest levels of vitamin $\mathrm{C}$ and copper, whereas the highest levels of zinc and calcium were observed in Ouro do Vale cv., as well as those of magnesium were shown in IAC 289-70 cv. At 12 months, however, the IAC 289-70 cv. showed significant levels of CP, $\beta$-carotene, iron, zinc, and sulfur, since it did not statistically differ from the other cultivars with the highest contents of these nutrients.

It was found that CLM from the analyzed cultivars and their respective ages showed high levels of these nutrients, compared with those of other leaves. Though, to recommend the use of the CLM in human diet, further studies concerning the antinutrients should be done.

\section{5 - REFERENCES}

[1] ALETOR, V. A.; ADEOGUN, O. A. Nutrients and antinutrient components of some tropical leafy vegetables. Food Chem., Oxford, v. 53, n. 4, p. 375-379, 1995.

[2] ALMAZAN, A. M.; BEGUM, F. Nutrients and antinutrients in peanut greens. J. Food Comp. Anal., Orlando, v. 9, n. 4, p. 375-383, 1996.

TABLE 6 - Average contents, g/100 g dry matter, of magnesium, calcium, phosphorus e potassium in cassava leaf meal at three ages of the plant.

\begin{tabular}{|c|c|c|c|c|c|c|}
\hline \multirow[t]{2}{*}{ Cultivars } & \multicolumn{3}{|c|}{ Magnesium } & \multicolumn{3}{|c|}{ Calcium } \\
\hline & $12 \mathrm{mo}$ & $15 \mathrm{mo}$ & $17 \mathrm{mo}$ & $12 \mathrm{mo}$ & $15 \mathrm{mo}$ & $17 \mathrm{mo}$ \\
\hline Ouro do Vale & $0.19 \mathrm{aB}$ & $0.20 \mathrm{aC}$ & $0.16 \mathrm{bD}$ & $1.95 \mathrm{bA}$ & $1.89 \mathrm{bA}$ & $2.21 \mathrm{aA}$ \\
\hline Maracanã & $0.20 \mathrm{aB}$ & $0.16 \mathrm{bD}$ & $0.19 \mathrm{aC}$ & $1.20 \mathrm{C}$ & $1.18 \mathrm{C}$ & $1.15 \mathrm{D}$ \\
\hline MANT.IAC & $0.20 \mathrm{~B}$ & $0.19 \mathrm{C}$ & $0.20 \mathrm{C}$ & $1.60 \mathrm{~B}$ & $1.58 \mathrm{~B}$ & $1.61 \mathrm{C}$ \\
\hline IAC 289-70 & $0.30 \mathrm{bA}$ & $0.32 \mathrm{bA}$ & $0.35 \mathrm{aA}$ & $1.56 \mathrm{cB}$ & $1.67 \mathrm{bB}$ & $1.80 \mathrm{aB}$ \\
\hline Mocotó & $0.29 \mathrm{aA}$ & $0.26 \mathrm{bcB}$ & $0.28 \mathrm{abB}$ & $0.98 \mathrm{cD}$ & $1.22 \mathrm{aC}$ & $1.11 \mathrm{bD}$ \\
\hline Cultivars & \multicolumn{3}{|c|}{ Phosphorus } & \multicolumn{3}{|c|}{ Potassium } \\
\hline Ouro do Vale & $0.28 \mathrm{bC}$ & $0.33 \mathrm{aA}$ & $0.28 \mathrm{bA}$ & $1.56 \mathrm{aABC}$ & $1.63 \mathrm{aA}$ & $1.16 \mathrm{bC}$ \\
\hline Maracanã & $0.29 \mathrm{aBC}$ & $0.28 \mathrm{aB}$ & $0.26 \mathrm{bBC}$ & $1.59 \mathrm{aAB}$ & $1.31 \mathrm{bC}$ & $1.12 \mathrm{cC}$ \\
\hline MANT.IAC & $0.30 \mathrm{aBC}$ & $0.27 \mathrm{bBC}$ & $0.26 \mathrm{bABC}$ & $1.49 \mathrm{aBC}$ & $1.38 \mathrm{bC}$ & $1.22 \mathrm{cBC}$ \\
\hline IAC 289-70 & $0.31 \mathrm{aB}$ & $0.28 \mathrm{bBC}$ & $0.24 \mathrm{cC}$ & $1.45 \mathrm{bC}$ & $1.41 \mathrm{bBC}$ & $1.63 \mathrm{aA}$ \\
\hline Mocotó & $0.33 \mathrm{aA}$ & $0.26 \mathrm{bC}$ & $0.27 \mathrm{bAB}$ & $1.63 \mathrm{aA}$ & $1.50 \mathrm{bB}$ & $1.27 \mathrm{cB}$ \\
\hline
\end{tabular}

Averages followed by the same small letter in the lines and capital letters in the columns do not differ with each other (Tukey test $\mathrm{p} \leq 0.05$ ).

TABLE 7 - Comparison of some leaf nutrients with the analyzed cassava leaf meal (CLM).

\begin{tabular}{|c|c|c|c|c|c|c|}
\hline \multirow[t]{2}{*}{ Nutrients } & \multicolumn{6}{|c|}{ In $100 \mathrm{~g}$ dry matter of leaves from } \\
\hline & Cole $^{1}$ & Carrot $^{2}$ & Beetroot $^{2}$ & Sweet potato ${ }^{3}$ & Peanut $^{4}$ & CLM $^{5}$ \\
\hline Protein (g) & - & - & - & 30.63 & 26.60 & 28.11 \\
\hline$\beta$-carotene $(\mathrm{mg})$ & - & - & - & 75.00 & 113.33 & 88.03 \\
\hline Vitamin C (mg) & - & 34.93 & 72.42 & 141.67 & 293.33 & 90.17 \\
\hline Iron (mg) & 3.96 & - & - & 14.67 & 16.00 & 16.69 \\
\hline Zinc (mg) & 1.12 & - & - & 3.33 & 5.33 & 5.08 \\
\hline Manganese (mg) & 1.93 & - & - & - & - & 14.12 \\
\hline Magnesium (mg) & 135.88 & - & - & 493.33 & 676.67 & 229.32 \\
\hline Calcium (mg) & $1,024.71$ & - & - & 623.33 & $1,236.67$ & $1,509.38$ \\
\hline
\end{tabular}

ínTOS [27]; ${ }^{2}$ SARTORELLI [28]; ${ }^{3}$ ALMAZAN et al. [3]; ${ }^{4}$ ALMAZAN \& BEGUM [2]; and ${ }^{5}$ Average contents independent from both cultivars and plant ages. 
[3] ALMAZAN, A. M.; BEGUM, F.; JOHNSON, C. Nutritional quality of sweet potato greens from greenhouse plants. J. Food Comp. Anal., Orlando, v. 10, n. 3, p. 246-253, 1997.

[4] ASSOCIATION OF OFFICIAL ANALYTICAL CHEMISTS - AOAC. Official methods of analysis of the Association of the Analytical Chemists, $16^{\text {th }}$. ed., Washington, 1995.

[5] AWOYINKA, A. F.; ABEGUNDE, V. O.; ADEWUSI, S. R. A. Nutrient content of young cassava leaves and assessment of their acceptance as a green vegetable in Nigeria. Plant Foods Hum. Nutri., Dordrecht, v. 47, n. 1, p. 21-28, 1995.

[6] BARRIOS, E. A.; BRESSANI, R. Composición química de la raiz y de la hoja de algunas variedades de yuca Manihot. Turrialba, San José, v. 17, n. 3, p. 314-320, 1967.

[7] CARVAlHO, V. D.; CHAGAS, S. J. R.; MORAIS, A. R.; PAULA, M. B.. Efeito da época de colheita na produtividade e teores de vitamina $\mathrm{C}$ e $\beta$-caroteno da parte aérea de cultivares de mandioca (Manihot esculenta Crantz). Rev. Bras. Mandioca, Cruz das Almas, v. 48, n. 1, p. 25-35, 1989.

[8] CARVALHO, V. D.; de PAULA, M. B.; JUSTER-JÚNIOR, E. S. G. Efeito da época de colheita no rendimento e composição química de fenos da parte aérea de dez cultivares de mandioca. Rev. Bras. Mandioca, Cruz das Almas, v. 41, n. 1, p. 43-59, 1985.

[9] CHAVEZ, A. L.; BEDOYA, J. M.; SÁNCHEZ, T.; IGLESIAIS, C.; CEBALlOS, H.; ROCA, W. Iron, carotene, and ascorbic acid in cassava roots and leaves. Food Nutri. Bull., Tokyo, v. 21, n. 4, p. 410-413, 2000.

[10] CORREAA, A. D. Farinha de folhas de mandioca (Manihot esculenta Crantz cv. Baiana) - efeito de processamentos sobre alguns nutrientes e antinutrientes. 2000, 108 f. Tese (Doutorado em Ciência de Alimentos), Universidade Federal de Lavras (UFLA), Lavras, 200.

[11] CORRÊA. A. D.; SANTOS, S. R. dos; ABREU, C. M. de; JOKL, L.; SANTOS, C. D. dos. Remoção de polifenóis da farinha de folhas de mandioca. Ciên. Tecnol. Aliment., Campinas, v. 24, n. 2, p. 159-164, 2004.

[12] EGGUM, O. L.The protein quality of cassava leaves. Br. J. Nutri., London, v. 24, n. 3, p. 761-769, 1970.

[13] FOOD AND AGRICULTURE ORGANIZATION OF THE UNITED NATIONS - FAO -. Brazil: the hunger of the missed meal, 2003. Disponível em: "http://www.fao.org/ english/newaroom/news/2003/13320-en.html” Acesso em: 25 out. 2005.

[14] FRANCO, G. V. E. Tabela de composição química dos alimentos. 8a ed., São Paulo: Atheneu, 1992, 230 p.

[15] GÓMEZ, G.; VALDIVIESO, M. Cassava foliage: chemical composition, cyanide content and effect of drying on cyanide elimination. J. Sci. Food Agric., Chichester, v. 36, n. 6, p. 433-441, 1985.

[16] MADRUGA, M. S.; CÂMARA, F. S. The chemical composition of "multimistura" as a food supplement. Food Chem., Oxford, v. 68, n. 1, p. 41-44, 2000.

[17] Malavolta, E.; VitTi, G. C.; Oliveira, S. A.. Avaliação do estado nutricional das plantas. Piracicaba: Potafos, 1989. $201 \mathrm{p}$.
[18] MOTTA, J. S.; FUKUDA, W. G.; COSTA, Z. M. Farinha da folha de mandioca: uma alternativa como complemento alimentar. Mandioca em Foco, v. 4, n. 1, p. 1-2, 1994.

[19] NAGATA, M.; YAMASHITA, I. Simple method for simultaneous determination of chlorophyll and carotenoids in tomatoes fruit. Nippon Shokuhin Kogyo Gakkaishi, Tokyo, v. 39, n. 10, p. 925-928, 1992.

[20] NWOKOLO, E. Leaf meals from cassava (Manihot esculenta Crantz) and Siam weed (Eupatorium odoratum L.) as nutrient sources in poultry diets. Nutr. Rep. Int., Los Altos, v. 36, n. 9, p. 819-826, 1987.

[21] PHUC, B. H. N.; OGLE, B.; LINDBERG J. E. Effect of replacing soybean protein with cassava leaf protein in cassava root meals based diets for growing pigs on digestibility and N retention. Animal Feed Sci. Technol., Amsterdam, v. 83, n. 3-4, p. 223-235, 2000.

[22] PIMENTEL, G. F. Curso de estatística experimental. 13ª ed., São Paulo: Nobel, 1990. 467 p.

[23] RAVINDRAN, V.; KORNEGAY, E. T.; WEBB K. E.; RAJAGURU, A. S. B. Nutrient characterization of some feedstuffs of Sri Lanka. J. Agric. Soc. Ceylon, v. 19, n. 1, p. 19-32, 1992.

[24] RAVINDRAN, V.; RAJAGURU, A. S. B. Effect of stem pruning on cassava root yield and leaf growth. J. Agric. Sci., New York, v. 25, n. 1, p. 32-37, 1988.

[25] RAVINDRAN. G.; RAVINDRAN, V. Changes in the nutritional composition of cassava (Manihot esculenta Crantz) leaves during maturity. Food Chem., New York, v. 27, n. 4, p. 299-309, 1988.

[26] ROGERS, D. J.; MILNER, M. Amino acid profile of manioc leaf protein in relation to nutritive value. Econ. Botany, Oxford, v. 17, n. 3, p. 211-216, 1963.

[27] SANTOS, M. A. T. Caracteriação química das folhas de brócolis e couve-flor (Brassica olearacea $L$.) para utilização na alimentação humana. 2000. $96 \mathrm{f}$. Dissertação (Mestrado em Ciência de Alimentos) - Universidade Federal de Lavras, Lavras, 2000.

[28] SARTORELLI, C. S. C. Caracterização química da parte aérea de cenoura (Daucus carota) e beterraba (Beta vulgaris), visando ao aproveitamento na alimentação humana. 1998, 98 f. Dissertação (Mestrado em Ciência de Alimentos), Universidade Federal de Lavras (UFLA), Lavras, 1998.

[29] SGARBIERI, V. C. Alimentação e nutrição: fator de saúde e desenvolvimento. São Paulo: Almed, 1987, 517 p.

[30] SILVA, D. J. Análise de alimentos: métodos químicos e biológicos. Viçosa: UFV, 1998. 166 p.

[31] SIQUIERA, E. M. A.; AZEREDO, I. T.; ARRUDA, S. F.; LIMA, S. M. D.; GONÇALVES, C. A.; SOUZA, E. M. T. Regional low-cost diet supplement improves the nutritional status of school children in a semi-arid region of Brazil. Nutr. Res., v. 23, n. 6, p. 703-712, 2003.

[32] STROHECKER, R.; HENNING, H. M. Análises de vitaminas: métodos comprovados. Madrid: Paz Montalvo, 1967. 428 p.

\section{6 - ACKNOWLEDGMENT}

The authors are grateful to Conselho Nacional de Desenvolvimento Científico e Tecnológico (CNPq)/Brazil, for financial support. 